\title{
AN OLD UYGHUR TEXT WRITTEN ON A WOODEN PLATE RECENTLY DISCOVERED IN THE TUYOQ GROTTOES IN TURFAN ${ }^{*}$
}

\author{
ABDURISHID YAKUP - LI XIAO \\ School of Chinese Ethnic Minority Languages and Literatures of Minzu University of China \\ Zhongguancun South Avenue, Haidian District, Beijing, 100081, P. R. China \\ Berlin Brandenburg Academy of Sciences and Humanities, Turfanforschung \\ Jägerstraße 22-23, Berlin 10117, Germany \\ e-mail: yakup@bbaw.de \\ School of Chinese Classics, Renmin University of China \\ Zhongguancun Great Evenue 58, Haidian District, Beijing, 100872, P. R. China \\ e-mail: haidaoqi@aliyun.com
}

This paper presents results of a primary investigation of an Old Uyghur text written on a wooden plate discovered in the fourth layer of the cave NK 9 in the Tuyoq Grottoes in Turfan during the excavations carried out by a joint team of Chinese archaeologists between the autumn of 2010 and early summer of 2011. The text on Side A of the wooden plate is from the Old Uyghur translation of the Viśeșa-cinti-brahma-pariprcchā 'Scripture of the inquiry of the Deity of Thinking' and closely matches the Siyi fantian suowen jing 思益梵天所問經, translated into Chinese by Kumārajīva. The text on Side B of the wooden plate is also of Buddhist content and seems to be by the same scribe. Presumably, it is also from the Old Uyghur translation of the Viśeșa-cinti-brahma-pariprechā, but it still needs a definite identification.

Key words: Old Uyghur, wooden plate, Viśeșa-cinti-brahma-paripṛcchā.

\section{Introduction}

A joint team of archaeologists from the Archaeological Institute of the Chinese Academy of Social Sciences, the Turfan Academy, and the Kucha Academy carried out excavations in the northern portions of the eastern and western zones of the Tuyoq Grottoes within the Turfan District of the Xinjiang Uyghur Autonomous Region, China between the autumn of 2010 and early summer of 2011. During the excavations, archaeologists discovered a considerable number of wall paintings, wall inscriptions, wooden frames, wood pens, and texts in various scripts, including Brāhmī, Chinese, Old Uyghur, Sogdian, and Tibetan. Three reports prepared by the Chinese scholars

* This paper presents part of the research which is carried out within the framework of the Specially Founded Research Project "Etymological Investigations on the Turkic Languages in China" by the National Social Sciences Foundation of China (Founding No. 11 \& ZD 130). 
Chen Ling 陈凌, Li Yuqun 李裕群 and Li Xiao 李肖 as a primary survey of these excavations have been published by the aforementioned three institutions (see $\mathrm{Li}$ et al. 2011; Chen et al. 2012a, 2012b). Li Xiao's article on the archaeological investigations in the Buddhist caves in Turfan provides more information on the findings of these excavations (see Li Xiao 2015). The excavations and investigations are still in progress. A joint report by Ding Xuelian 丁晓莲 and Wang Long 王龙 (2015) from the Turfan Museum briefly outlines some results of further investigations carried out in 2013 and 2015. However, thus far, only very limited information has been given on the Old Uyghur fragments which were discovered during these excavations. Chen et al. (2012b, Plate 11, Photo 3) provides a photo of the longest Old Uyghur inscription in the cave NK 10, and the aforementioned article by Li Xiao (2015, p. 155, Photos 47-49 and p. 152, Photo 33) includes a clearer photo of the same wall inscription as well as a photo of another wall inscription, making both inscriptions available for the scholarly world. ${ }^{1}$ Li Yuan (2010) provides a photo of an Old Uyghur colophon written on the back side of a long Chinese scroll she restored. Furthermore, she also publishes a photo of another Old Uyghur text, though only two lines of it are visible (Li 2010, p. 110, Photo 4 and p. 108, Photo 1). In the final phase of this research, we became aware of the publication of a fragment (TLF 14894) of the wellknown Old Uyghur Buddhist text Altun Yaruq Sudur 'The Golden Light Sūtra', namely the Suvarnaprabhāsasūtra, which, according to the author of the paper, was discovered in the east side, perhaps from the east zone of the Tuyoq Grottoes, in 2011 (see Zhang 2017, p. 411). ${ }^{2}$ Before that only two block-printed fragments of the Old Uyghur Sitātapatrādhāraṇī had been published from the new findings in Tuyoq (Zieme 2014).

This paper presents the results of a primary investigation of an Old Uyghur text written on a wooden plate which was discovered in the fourth layer of the cave NK 9 (the temporary shelf number is: 工程編2区 3 , 临1號 Gongcheng bian 2 qu san, lin 1 hao 'Project number 2 nd area 3 , temporary number 1 ). It was found together with anotherr piece of a wooden object with Old Uyghur letters and a stone piece containing some Old Uyghur words (Chen et al. 2012b, p. 22). Unfortunately, on the photos of the latter two published in Chen et al. (2012b, Plate 12, Nos 4 and 6), merely some words,

\footnotetext{
${ }^{1}$ A primary result of research on this wall inscription was just completed by Li Xiao and Abdurishid Yakup.

${ }^{2}$ Regrettably, the text was published in a very unusual form and quality. First of all, it includes numerous misinterpretations. To take only one example, the translation of Lines $\mathrm{r} 05-\mathrm{r} 06$ (p. 413) as 'Thus the God of Buddha was gracious' is not proper, it must be interpreted something like 'The Buddha, the god of gods, preached like this'. Addition of the illogical commentary 'This sentence is an additional phrase' directly under the aforementioned translation is rather curious. Secondly, it uses different transcriptions in the title of the paper and the abstract from the one used in the transcription. Thirdly, the only commentary to the Old Uyghur text on p. 413 is " $01-06$ Parallel in BT XVIII, 0456-0457 [äši]dgäli bolur bo nom ärdini[g ulatı] kšanti q1lmaqli $\gamma$ qutlu $\gamma$ bo [nomu tngri tngri]si burxan [mun]čula[yu yrlıqadi]. However, in BT XVIII, 0456-0457 one finds

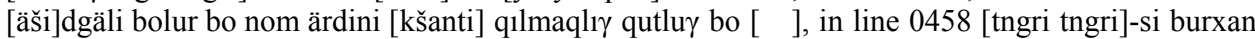
yrlıqa $] \mathrm{m} l[\check{\mathrm{s}}]$, which clearly differ from the cited text. Even the reconstruction of the pagination as baštınq1 üč [yigirmi (sic!) p)tr is not certain. I refrain from discussing them here in detail.
} 
bo äv/// 'this house(?)' on the wooden object, and one incomplete clause /'z mys m(ä)n kim ym[ä] 'I did [ ], whoever else [ ]' on the stone piece, are visible.

\section{On the Old Uyghur Text on the Wooden Plate}

The wooden plate with the Old Uygur text which is the subject of this paper was kept in the Turfan Museum until the end of 2010. However, the exact place where it is currently kept is not clear. According to the records of the Turfan Museum, it is $42.7 \mathrm{~cm}$ long, $11.2 \mathrm{~cm}$ wide, and $2.7 \mathrm{~cm}$ thick. Two sides of the wooden plate contain Old Uyghur text in the cursive type and 38 lines on each side. The text on the one side (henceforth Side A) is relatively well preserved, though the script at the beginning part of Side A is faded and is difficult to recognise. The other side (henceforth Side B) shows fairly heavy damage on the left edge between lines 5-8 and on the right edge between lines 25-29 through a fairly big hole. It is not clear yet why these two holes have been cut there. Nevertheless, the holes were filled with two small wooden pieces. With the exception of the nine lines at the end of the wooden plate, the script on Side $\mathrm{B}$ is faded, and most part of the text is hard to recognise.

We successfully identified the text on Side A. It is from the Old Uyghur translation of the Viśeșa-cinti-brahma-paripṛcchā 'Scripture of the inquiry of the Deity of Thinking', an influential Buddhist text on the formation and development of Chan Buddhism (see Wang 1997, p. 36). The Old Uyghur text closely matches the Siyi fantian suowen jing 思益梵天所問經, translated into Chinese by Kumārajīiva in 402 (Taishō, vol. 15, No. 586). It parallels two parts of the fourth chapter of Book One, approximately the Taisho volume 15, No. 586, 39b24-39c3. However, the identification of the Old Uyghur text on Side B was not possible at the moment, though the text is also of Buddhist content and seems to be by the same scribe. Presumably, it is also from the Old Uyghur translation of the Viśeșa-cinti-brahma-pariprcchā. The use of the rare Buddhist term arıyın kälmiš for Tathāgata in the text on Side A is one of the points which led to this assumption. It occurs twice on Side A of the same wooden plate. If the text on Side B is also from Viśeșa-cinti-brahma-pariprcchā, perhaps, it translates parts of the last and longest passage of the fourth chapter of Book One in which Tathāgata is frequently mentioned, precisely Taishō volume 15, No. 586, $39 \mathrm{c} 3-40 \mathrm{~b} 12$. However, this assumption deserves further investigation and is difficult to proove at the present stage of our research due to the critical status of Side B.

Aside from Kumārajīva's translation, the Viśeșa-cinti-brahma-paripṛcchā is also known in two further Chinese translations, the Chixin fantian suowen jing 持心梵 天所問經 by Dharmarakșa which was done in the 3rd century, and the Sheng siwei fantian suowen jing 胜思惟梵天所問經 which was completed in the 6th century by Bodhiruci. The first one was included in the 15th volume of the Taishō Tripitaka as text No. 585, while the second one was included as text No. 587 in the same volume. However, the Old Uyghur text shows clear divergences to these two texts.

The Viśeșa-cinti-brahma-paripṛcchā also exists in Tibetan translation. According to the reconstruction by T. Goshima based on the Tibetan text, the original Sanskrit 
title of the text is Ārya-...brahma-viśeșa-cinti-brahma-paripṛcchā...-nāma-mahāyānasūtra (see Goshima 2009a, p. 143). The Tibetan translation of the text comprises six volumes and exists in both manuscript and printed versions (Goshima 1985 and 1988). The main part of the Old Uyghur text basically matches the Tibetan version, however, some parts also show clear divergences. For instance, in the Tibetan text we find the parable "one can describe, but there is no form that can be seen through eyes" (see Goshima 2011, p. 103). ${ }^{3}$ However, there is no comparable parable or expression in the Old Uyghur translation.

Several Sogdian fragments of the text have also been discovered in Shorchuq in the western part of Xinjiang, and they were published by the late professors Koggi Kudara and Werner Sundermann (Kudara-Sundermann 1991). According to their research, Kumārajīva's Chinese translation is closest to the Sogdian text (Kudara-Sundermann 1991, p. 247).

Besides the sūtra text, there are some commentaries to Viśeșa-cinti-brahmaparipṛcchā. One of them is the Sheng siwei fantian jing lun 胜思惟梵天所問經論 written by Vasubandhu and translated into Chinese by Bodhiruci. The text is included in the 26th volume of the Taishō Tripitaka as text No. 1532. It includes citations from the sūtra text which show similarities to the Old Uyghur translation of the Viśeșacinti-brahma-paripṛcchā. ${ }^{4}$ However, the citations show clear divergences from the Old Uyghur text.

Interestingly, among the findings of the newest Tuyoq excavations, there is a Chinese fragment of the Siyi fantian suowen jing 思益梵天所問經 translated by Kumārajīva, and it is from Cave K8 on the northern portion of the eastern zone of the Tuyoq Grottoes (see Chen et al. 2012a, p. 15, Plate 5, No. 5). There are also four small Chinese fragments of the Siyi fantian suowen jing 思益梵天所問經 in the Berlin Turfan collection, namely $\mathrm{Ch} / \mathrm{U} 6082$ (T II T 1411), Ch/U 6197 (T III D 271.50), $\mathrm{Ch} / \mathrm{U}$ 6544 (T II T 1527), and Ch/U 8614 (T III T 509). All of them have a Chinese text on recto and an Old Uyghur text on verso. Clearly, the Old Uyghur text was written later than the Chinese one, which is usual among the manuscripts of similar type discovered in Dunhuang and Turfan. More interestingly, judging from the finding sigla, with the exception of Ch/U 6197 (T III D 271.50) which was discovered in Dakianusšähri, the remaining three fragments are also from Tuyoq. This clearly testifies to the fact that Kumārajīva's Chinese translation of the Viśeșa-cinti-brahma-pariprecchā, one of the important influential doctrines on Chan Buddhism, was known to the Old Uyghur Buddhists in Turfan, both in the Chinese original version and in the Old Uyghur translation. However, it is not clear what kind of role Chan Buddhism had played in Turfan Buddhist society. What can be said at the moment is that the Viśeșa-cinti-brahma-pariprechā is not the only text discovered in Tuyoq to be connected to Chan Buddhism. At least one more fragment (U 4245 (T II T 660)) from the Old Uyghur translation of the Da fangguang yuanjue xiuduoluo liao yijing 大方廣圓覺修多羅了義經 (Taishō, Vol. 17, No. 842), which A. Charles Muller translates as 'Great Corrective Extensive

\footnotetext{
${ }^{3}$ The English translation is based on the Japanese translation of the text by T. Goshima.

${ }^{4}$ Please compare the text from Taishō Vol. 26, No. 1532, 350a20 to Taishō Vol. 26, No. $1532,350 \mathrm{~b} 01$.
} 
Perfect Enlightenment Sutra of the Complete Doctrine' and an influential doctrine of Chan Buddhism (Muller 1999, p. 41), was also discovered in Tuyoq (Zieme 1999, p. 455).

The Old Uyghur translation of the Viśeșa-cinti-brahma-paripṛcchā is important from two points of view. Firstly, it is the hitherto-known first Old Uyghur Buddhist sūtra written on a wooden plate, though it is not clear why this Buddhist sūtra was written on a wooden plate instead of paper which was common for Old Uyghur Buddhist texts. Secondly, it is the hitherto-known Old Uyghur translation of the Viśeșa-cinti-brahma-paripṛcchā which refreshes our knowledge on Old Uyghur Buddhism. Needless to note, there are a considerable number of Old Uyghur texts written on wooden objects, including inscriptions, alliterative poems, scribbles, and writing exercises. ${ }^{5}$ However, as we have mentioned in the preceding lines, thus far no other Old Uyghur Buddhist sūtra written on wooden objects has been found.

The present research is mainly based on the photo and the transcription which was done by A. Yakup who had a chance to directly examine the text during his participation in "The Fourth International Conference on Turfan Studies and Turfan Forum on Old Languages of the Silk Road: The History behind the Languages", convened by the Turfan Academy in October 2010, with the kind support of Professor Li Xiao, former director of the Turfan Museum and Turfan Academy.

\section{Edition of the Old Uyghur Text on the Wooden Plate}

\subsection{Transcription, Translation of the Old Uyghur Text on Side A and the Chinese Parallel Passage}

\subsubsection{Transcription}

\begin{tabular}{|c|c|}
\hline A01 & ] nom// bulmı̌s(?) [ ] \\
\hline A02 & ]///pw //// // \\
\hline A03 & ]$/ \mathrm{y} /[\mathrm{]}] / / / / /$ \\
\hline A04 & ]$/ \mathrm{p} / / / / /[$ \\
\hline A05 & ]$/ t / / / 1 \mathrm{t} / / / \mathrm{l}^{\prime} \mathrm{r}$ \\
\hline A06 & ] p[ ]lkw // lahšanlarqa (?) \\
\hline A07 & ]//// ögirgülük [ ] \\
\hline A08 & ]yq bir[i] kdür//[ ] \\
\hline A09 & ] burhanlarnıng yertinčütä \\
\hline A 10 & ] b(ä)lg[ür]m[ä] $\mathrm{k}(?)$ nirvan \\
\hline A11 & ]/' bodulturmadačı \\
\hline A 12 & ] amtıma täginür . nom- \\
\hline A13 & ngız ärsär ymä \\
\hline A1 & ?)] nomlayuluqsuz no[m]- \\
\hline & nom]latıngız . ögtüngüz \\
\hline
\end{tabular}

\footnotetext{
${ }^{5}$ For detailed information, see Moriyasu (2001), Raschmann (2016).
} 


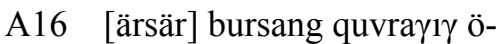

A17 [gmä]ksiz bursangli $\gamma$

A18 [quvray ärür]. an1 üčün $\mathrm{t}(\mathrm{ä})$ ngrim

A19 [ ] bo nomunguz. alqu (+) yertinčü-

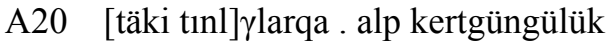

A21 [ärür .] inčä qaltı oottın

A22 [suv] öngirmäk suvtın yana

A23 [y]mä oot öngirmäkingä alp

A24 [kert]güngülük täginür ärsär /[ ] ]

A25 [ ]/ taq1 (?) ymä (+). nizvanılı $\gamma$ tın

A26 [ym]ä bodi tuyunmaqli $\gamma$

A27 [ön]girmäk bodi [tuy-]

A28 [un]maqlı $\gamma$ tın (nizvanılı $\gamma$ ) \{suvt[1n]

A29 [ ] oot\} öngirmäkingä

A30 [ym]ä alp kertgüngülük tägin-

A31 [ür. nä] üčün tep tesär .

A32 [arı $\gamma]$ ın kälmiš a siz bulu y(a)rl1-

A33 [qamı̌̌ sı] äzüg igid tätrülmäk töz-

A34 [lüg] nizvanılarnıng $(+)^{6}$ köni tözintä

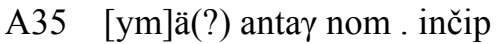

A36 [ ] yn bululmayuluq nomlar(?)

A37 [ ] ] č’ nomları $(+)^{7}$ ymä(?) bodsuz b(ä)lgüs[üz]

A38 [ ] ]wn adir(?) //I/I/I/I//I/

\subsubsection{Translation}

$\begin{array}{ll}\text { A01-A05 } & [\quad] \text { dharma(?) [] having obtained(?) [....... }] \\ \text { A06 } & {[\quad] \text { to signs and lakșaṇas(?) }} \\ \text { A07 } & {[\quad \text { ] must be praised [ ] ] }} \\ \text { A08 } & \text { bring [] together [ } \\ \text { A09-A10 } & \text { appearance(?) of Buddhas in the world [ ] nirvāṇa [ ] } \\ \text { A11 } & \text { one which have [ ] be attached [ ] }\end{array}$

A12 [ ] undertakes at the moment, too.

A13-A20 Even though you have preached, [it is] the dharma that should not be preached. Even though you also have praised the assembly, [it is the] assembly that should not be praised. Therefore, my Lord, this doctrine of you [is] hard to trust for the living beings all over the world.

A21-A24 Just like one hardly ventures to trust to the emergence of [water] from fire and again hard to trust to the emergence of fire from water.

A25-A31 [ ] moreover, one also hardly [venture]s to trust to the emergence of bodhi, namely enlightenment from afflictions (kleśa), and to the emer-

${ }^{6}$ Only l'r nynk is an addition.

${ }^{7}$ Only nom is an addition. 
gence of afflictions from bodhi, that is the enlightenment. If one asks "Why?"

A32-A37 O, Purely-Come-One, in the true root of afflictions (kleśa) which are false, lying (abhūta) and of distortions (viparyaya), you [also](?) deigned to obtain the doctrine like that. On the other hand, [ ] the doctrines that cannot be obtained [ ] as [ ] their doctrines (are) also without form and [without] sign [ ] $[\ldots \ldots]$

\subsubsection{Chinese Parallel Passage}

The Old Uyghur text on Side A of the wooden plate has the following parallel passage in the Chinese Buddhist canon (Taishō, Vol. 15, No. 586, 39b23-39c3), and presumably, this parallel passage had been the basis for the Old Uyghur text on Side A of the wooden plate: ${ }^{8}$

世間貪著善法。而是法無善無非善。世間貪著樂。而是法無苦無 樂。世間貪著佛出世。而是法無佛出世。亦無涅槃。雖有説法 而是法非可説相。雖讃説僧而僧即是無爲。是故此法一切世間之 所難信。譬如水中出火火中出水難可得信。如是煩惱中有菩提。 菩提中有煩惱。是亦難信。所以者何。如來得是虚妄煩惱之性。 而無法不得。有所説法亦無有形。雖有所知亦無分別。

\section{Tentative English Translation}

The people of the world are attached to good dharma. However, the dharma has no good dharma and not good dharma. The people of the world are attached to happiness. However, the dharma has no suffering and happiness. The people of the world are attached to the appearance of Buddhas in the world. However, the dharma does not have appearance of Buddhas in the world, and it also does not have nirvāna. Even though there exists exposition of the dharma, and the dharma may not have characteristics of discourse. Even though extolling the assembly, assembly is just unconditioned. Due to this reason the people of the world hardly trust to this dharma, just like hard to trust to the emergence of water from fire and again the emergence of fire from water. In this way, it is also hard to believe there is enlightenment in afflictions, and there are afflictions in enlightenment. If one asks "why?" What Tathāgata has attained is of nature of delusion and afflictions. However, there is no dharma that cannot be attained. The dharma which was taught also does not have marks. Even though there are cognitive objects, they are not to distinguish.

\footnotetext{
${ }^{8}$ Quoted from http://21dzk.1.u-tokyo.ac.jp/SAT/satdb2015.php?lang=en.
} 


\subsection{Transcription and Translation of the Old Uyghur Text on Side B}

\subsubsection{Transcription}

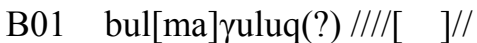

B02 // saqintımiz(?) //[

B03 []kwčy brahman (?) kertü(?)

B04 töz(?) yangl[uq(?) ]//

B05 adinlar(?) [ ]/

B06 p/// yavlaq [ ]/

B07 //// nirvan /[ ] ]//

B08 /////tä)ngri /[ ] ]/

B09 öčmäksiz üzülmäk-

B10 siz /w/[ ] //// ///m'/

$\mathrm{B} 11 \operatorname{kim}[\mathrm{]} / /[\mathrm{]} / /[\mathrm{]}$

B12 p/ wn $/ / /(+(?) / / / /[$ ] $/ / / /[$ ]

B13 mys ärsär tänglägülük //

B14 yw/y // lyk keng(?)

B15 /// bo arıүın kälmiš (?)

B16 wn tesä[r(?)] //wyz ///y//

B17 inčä nomlamıš(?) ol [ ]

B18 pw //// nä üčün [tep tesär( ?)]

B19 tükädmiš(?) /// ///[ ]

B20 $1 / /$ t'/mys $/ / /[$ ] ]

B21 $/ / / /[$ ] yw////[ ]

B22 [ ] buši pramitning[(?)]

B23 tükäl bilgä biliglig

B24 'ky bil[gä b]il[ig]li[g(?) ]

B25 /// t///[]/y//[ ]

B26 l'r nynk [ ] uma[ray?]

B27 ////nkw/[ ] ynk

B28 küč(?) ol [ ] tep

B29 [ ] nom

B30 //// /[ ] bo q11[1nč $]$

B31 [ ]ynč tilämäk[ ]

B32 tükätmäk ädgü q1lın[ [̌ ]

B33 ü[t]lätäči ol . ari $\gamma[1 \mathrm{n}]$

B34 kälmišlärning(?) ///[ ]

B35 tušdačı qatır y[av]1[aq] (+) tözlüg no[m]-

B36 lar ol. alp tetgülük / [ ]

B37 alqu nizvanıliy tep [ ]

B38 wn tuttačılar ol. //[ 


\subsubsection{Translation}

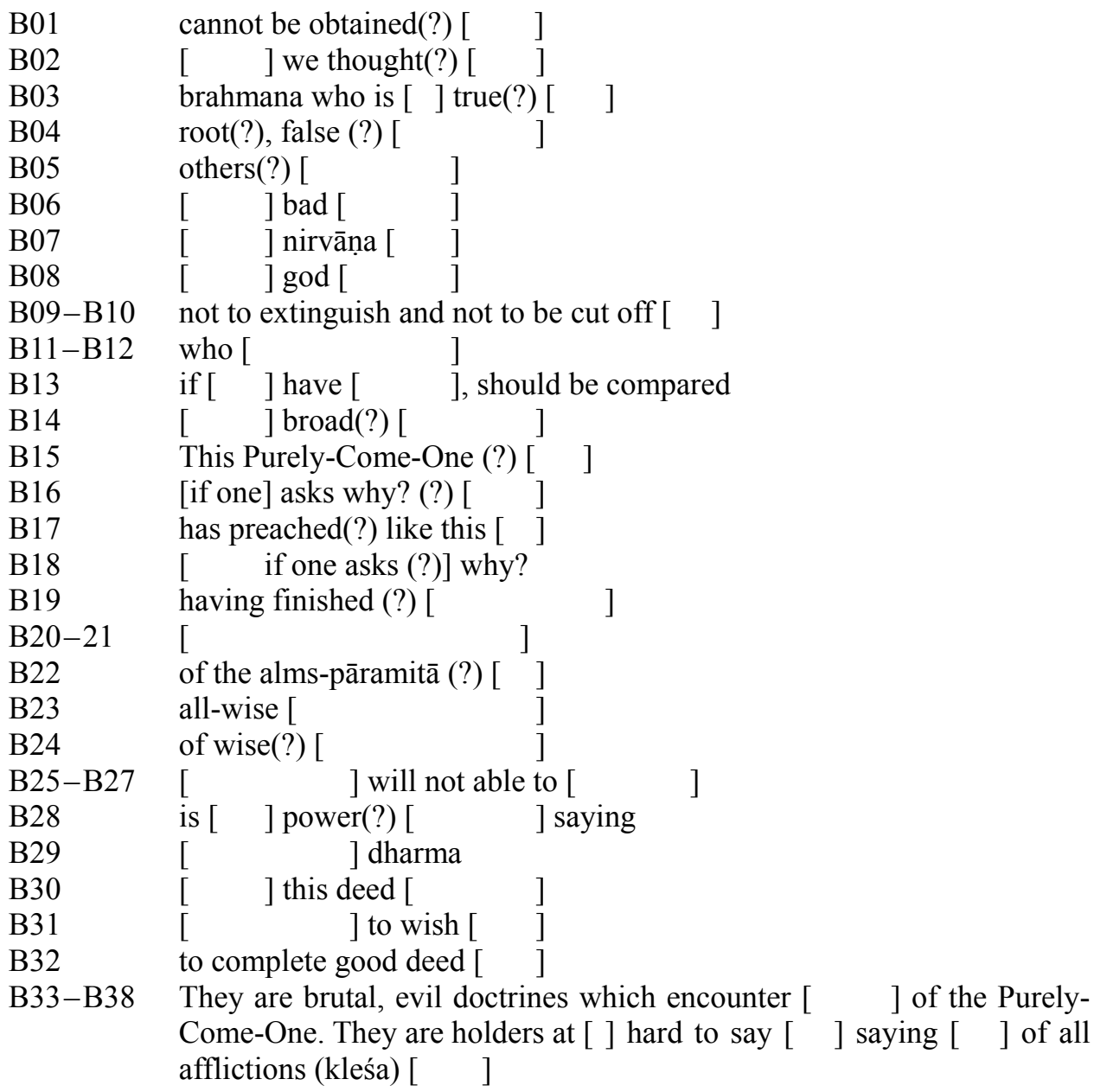

\subsection{Commentary}

A01 bulmıš(?): Clearly, this word can also be read as bolmıš. The context does not provide clear information for making a selection between them. We selected bulmıš(?) with the assumption that the preceding word nom 'dharma' might be in the accusative.

A06 p[ ]kw // lahšanlarqa(?): Perhaps, the first word might be reconstructed b[(ä)l]gü 'sign', however, the reading of the following word lahšanlarqa(?) is not certain.

A07 ögirgülük: Presumably, this word is connected to 樂 le 'laugh, happy' in the Chinese text. However, the Chinese text shows the same character twice, see 
Taishō, Vol. 15, No. 586, 39b23-25, and it is difficult to judge which one might have served as the basis for this word.

A09-10 burhanlarnıng yertinčütä [ ] b(ä)lgürmäk: Might be translated as 'appearance of Buddhas in the world [ ]', here it stands for Chin. 佛出世 Fo chu shi 'the Buddha appears' or 'appearance of the Buddha'. The absence of the possessive suffix after b(ä)lgürmäk is noteworthy, though it is not unusual in Late Old Uyghur texts. For more detailed descriptions of similar instances, see Zieme and Kara (1978, pp. 14-17).

A11 bodulturmadač 1 is the negative future of the causative verb bodultur- 'having been attached', formed by means of the causative ending -tUr on the basis of the passive verb bodul- 'to be attached'. Here it translates Chin. 著 zhuo 'attachment', 'clinging', which stands for Sanskrit sakta and adhyavasāna of the same meaning.

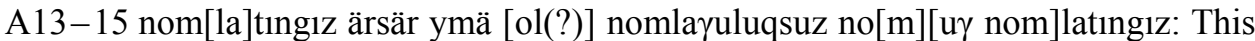
sentence translates to Chin. 雖有説法而是法非可説相 sui you shuofa er shi fa fei ke shuo xiang 'Even though there exists exposition of the dharma, and this dharma may not have characteristics of discourse' (Taishō, Vol. 15, No. $586,39 \mathrm{~b} 26$ ), which might be translated as 'Even though there is an exposition of the teachings (dharma), and this teaching may not have the characteristics of discourse'.

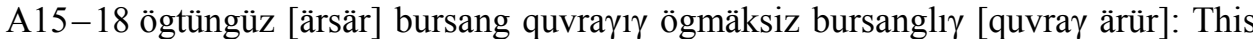
sentence might be rendered as 'If you also have praised the assembly, [it is the] assembly that should not be praised' and here it stands for Chin. 雖讚說僧, 而僧即是無為 (Taishō, Vol. 15, No. 586, 39b26-27), which might be translated as 'Even though extolling the assembly, assembly is just unconditioned'. The old Uyghur term for 無為 wuwei 'unconditioned' (asamskrta) is etigsiz; see Shōgaito (2008, pp. 547-548 and 2014, p. 244). It is not clear why here ögmäksiz 'should not be praised' was used instead of the common term etigsiz. From the spelling, it is difficult to consider it as a misspelling of etigsiz. Perhaps, the word which follows bursangli $\gamma$ 'of assembly' is not quvra $\gamma$ 'assembly' as seen in the text, but should be etigsiz, though it seems very unlikely.

A21-23 oottın [suv] öngirmäk suvtın yana [y]mä oot öngirmäk: Might be translated as 'emergence of [water] from fire and again the emergence of fire from water', translates Chin. 水中出火火中出水 shui zhong chu huo huo zong chu shui. We find similar expression in Wilkens (2016, 11. 10338-10339): suvdin oot üngäy : ootdın suv üngäy (I express my thanks to Professor P. Zieme for this note). One obvious difference between our text and the passage in Wilkens (2016) is that our text uses the noun verb öngirmäk 'emergence' derived from the causative verb öngir- 'to make something turn into something', 'to have something emerge' which is derived on the basis of the verb öng- 'to turn something into something' by means of the causative suffix -(U)r, while the passage in Wilkens (2016) has the verb ün- 'to rise'. To explain öng- as 'to approach stealthily and with evil motives' (see Erdal 1991, pp. 718-719) is fairly questionable. The instances both in Qutad $\gamma u$ Bilig (1. 4265) and in Türkische Turfan- 
texte I (11. 217-218) do not support this explanation. In the case of Qutadyu Bilig, yağı bolsa ešin öngär cānınga simply means 'if your friend turns hostile, he will sap your very soul' (see Dankoff 1983, p. 178), and yašuruq1 iši üzä qapırıng öngürsär in Türkische Turfantexte I might be better translated as 'if one makes your door turn into something else through secret things'. Note that in our text the verb is not öngür- but öngir- (the spelling is 'wynkyr). As far as I know, thus far it has not been attested in this form in Old Uyghur texts.

A23-24 alp [kert]güngülük täginür ärsär: Might be translated as 'If one hardly [venture]s to trust'. Interesting is here the use of the auxiliary verb tägin- expressing modesty together with a verb in -gUlXk coding necessity. It seems to me that -gUlXk tägin- contrasts with -gUlXk är- with regard to [ \pm modest possibility], of which -gUlXk är- is used to code possibility and ability, whereas -gUlXk tägin- codes modest possibility. The latter occurs again in lines 30-31. For -gUlXk är-, see Erdal (2004, p. 260). In the Chinese text, we find 難信 nanxin 'hard to believe' or 'difficult to trust'.

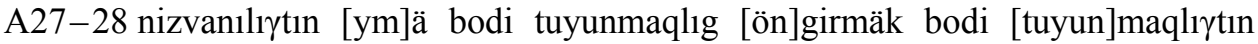
(nizvanılıү) öngirmäkingä [ym]ä alp kertgüngülük tägin[ür]: This sentence might be rendered as 'Moreover, one also hardly [venture]s to trust to the emergence of bodhi, namely enlightenment from afflictions (kleśa), and to the emergence of afflictions from bodhi, that is the enlightenment'. It renders the Chinese sentence 如是煩惱中有菩提, 菩提中有煩惱, 是亦難信 rushi fannao zhong you puti, puti zhong you fannao, shi yi nanxin 'If there is enlightenment in afflictions, there are afflictions in enlightenment, it is also difficult to believe'. In the Old Uyghur text, the word for nizvanıli $\gamma$ after bodi [tuyun]maqli $\gamma$ tın is missing. Instead, the scribe adds suv[ ] oot, which seems to be superfluous. We added nizvanıli $\gamma$ after bodi [tuyun]maqli $\gamma$ tın and erased suv[ ] oot in this edition.

A33-34 igid äzüg tätrülmäk töz[lüg] nizvanılarnıng köni tözintä: This phrase might be translated as 'in the true root of afflictions (kleśa) which are of false, lying (abhūta) and distortions (viparyaya) of nature'. It stands here for Chin. 虛妄煩 惱之性 xu wang fan nao zhi xing 'in the nature of delusion and afflictions'. The Buddhist term tätrülmäk usually renders Chin. 颠倒 diandao 'distortions', and there is no corresponding Chinese word in the corresponding Chinese phrase. However, in the preceding passage of the same text we find 虛妄顛倒 所起煩惱 xu wang diandao suoqi fannao which contains 颠倒 diandao, the exact Chin. correspondence of tätrülmäk as a Buddhist term.

A36 bululmayuluq nomlar(?): This phrase might be translated as 'the doctrines which cannot be attained', stands here for Chin. 無法 wufa 'nonexistent' which usually renders Skt. abhāva, asat, adharma etc., one of the key terms of Chan Buddhism; see Nakamura (1981, 1345d); Digital Dictionary of Buddhism, entry 無法.

B01 bul[ma]yuluq(?): Negated necessity form of the verb bul- 'to find', 'to obtain' which might be translated as 'should not be attained' or 'should not be obtained'. We temporarily translated it 'cannot be obtained'. It should be noted that the reading is not certain. 
B13 mys: Presumably, together with the damaged part of the preceding line, might be reconstructed as arıүn kälmiš 'Purely-Come-One'; however, as the letters in the preceding line are not clearly visible, the reading is not certain.

B22 buši pramitning[(?)]: Might be translated as 'of the alms-pāramitā( ?)'. However, the reading of the second phrase pramitning[(?)] is not certain.

B34 arr $\gamma[1 n]$ kälmišlärning(?): Might be translated as 'of these Purely-Come-Ones'. However, the reading of the genitive suffix -ning which follows arı $\gamma[$ in] kälmišlär is not certain. Note that arıyın kälmiš is another Old Uyghur term for Tathāgata besides the most common term ančulayu kälmiš 'Thus-Come-One'. It also occurs in some other Old Uyghur texts; see Röhrborn (2015, p. 238) and Yakup (2010, B060).

\section{References}

Bang, Willi-von Gabain, Annemarie (1929): Türkische Turfan-Texte. I. Bruchstücke eines Wahrsagebuches. Berlin, Reimer (Sitzungsberichte der Preußischen Akademie der Wissenschaften, Philologisch-Historische Klasse 15).

Chen Ling 陈凌-Li Yuqun 李裕群-Li Xiao 李肖 (2012a): Xinjiang Shanshan xian Tuyugou dongqu beice shiku fajue jianbao 新疆鄯善县吐峪沟东区北侧石窟发掘简报 [A survey of the excavation carried out in the eastern portion in the Tuyoq Grottoes in Pichan County of Xinjiang]. Kaogu 考古 [Archaeology] No. 1, pp. 7-16, +6 plates.

Chen Ling 陈凌-Li Yuqun 李裕群 - Li Xiao 李肖 (2012b): Xinjiang Shanshan xian Tuyugou xiqu beice shiku fajue jianbao 新疆部善县吐峪沟西区北侧石窟发掘简报 [A survey of the excavation carried out in the northern portion in the Tuyoq Grottoes in Pichan County of Xinjiang]. Kaogu 考古 [Archaeology] No. 1, pp. 17-22, +6 plates.

Dankoff, Robert (1983): Yūsuf Khāș Hajib, Wisdom of Royal Glory (Kutadgu Bilig): A TurkoIslamic Mirror for Princes. Translated, with an introduction and notes by Robert Dankoff. Chicago, University of Chicago Press.

Digital Dictionary of Buddhism. URL: http://www.buddhism-dict.net/ddb/

Ding Xiaolian 丁晓莲 - Wang Long 王龙 (2015): Tuyugou shikusi xian zhongqu kaogu xin shouhuo 吐峪沟石窟寺西岸中区考古新收获 [New archaeological discoveries in the central area of the west bank of the Tuyoq cave monasteries]. Tulufanxue yanjiu 吐鲁番学研究 [Turfanological research] No. 2, pp. 155-156, + 1 plate.

Erdal, Marcel (1991): Old Turkic Word Formation I-II. Wiesbaden, Harrassowitz Verlag (Turcologica 7).

Erdal, Marcel (2004): A Grammar of Old Turkic (Handbook of Oriental Studies. Section 8 Uralic \& Central Asian Studies 3). Leiden-Boston, Brill.

Goshima, Kiyotaka 五島清隆 (1985): “Bontenshomonkyō” kenkyū nōto (1): Seizō daizōkyō nishahon o chūshin to shita Kan, Zōyaku kan no idō ni tsuite『梵天所問経』研究ノ一ト (1): 西蔵大蔵経二写本を中心とした漢・蔵訳間の異同について [Notes to the Brahmapariprcchā (1): On the divergences between the Chinese and Tibetan translations based on

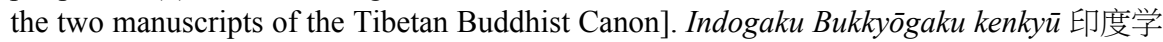
仏教学研究 [The journal of Indian and Buddhist studies] Vol. 34, No. 1 (December 1985), pp. 380-376.

Goshima, Kiyotaka 五島清隆 (1988): “Bontenshomonkyō” kenkyū nōto (2): Viśeșacintin to Jālinīprabha no ni bosatsu ni tsuyite 『梵天所問経』研究ノ一ト (2): Viśeșacintin と Jālinīpra- 
bha の二菩薩について [Notes to the Viśeșa-cinti-brahma-paripṛcchā (2): On the two Bodhisattvas Viśeșacintin and Jālinīprabha]. Indogaku Bukkyōgaku kenkyū 印度学仏教学研 究 [The journal of Indian and Buddhist studies] Vol. 36, No. 2, pp. 50-55.

Goshima, Kiyotaka 五島清隆 (2009a): “Chibetto yaku "Bontenshomonkyō": wa yaku to yaku chū (1): チベット訳『梵天所問経』－和訳と訳注 (1) [English title: An annotated Japanese translation of the Tibetan version of the Brahma-pariprechā (1)]. Indogaku Chibettogaku $k e n k y \bar{u}$ 印度学チベット学研究 [The journal of Indian and Tibetan studies] 13, pp. 141184.

Goshima, Kiyotaka 五島清隆 (2009b): “Chibetto yaku "Bontenshomonkyō”: wa yaku to yaku chū (3): チベット訳『梵天所問経』-和訳と訳注(3) [English title: An annotated Japanese translation of the Tibetan version of the Brahma-paripṛcchā (3)]. Indogaku Chibettogaku kenky $\bar{u}$ 印度学チベット学研究 [The journal of Indian and Tibetan studies] 15, pp. 196230.

Goshima, Kiyotaka 五島清隆 (2011): “Chibetto yaku "Bontenshomonkyō”: wa yaku to yaku chū (2): チベット訳『梵天所問経』- 和訳と訳注(2) [English title: An annotated Japanese translation of the Tibetan version of the Brahma-pariprcchā (2)]. Indogaku Chibettogaku kenkyū 印度学チベット学研究 [The journal of Indian and Tibetan studies] 14, pp. 89125.

Kudara, Kōgi-Sundermann, Werner (1991): Fragmente einer soghdischen Handschrift des Viśeșacinti-brahma-paripṛcchā-sūtra. Altorientalische Forschungen Vol. 18, No. 2, pp. 246-263.

Li Xiao 李肖 (2015): Jinnian Tulufan Fojiao shikusi kaogu de xin shouhuo 近年吐鲁番石窟寺 考古的新收获 [New discoveries of archaeological investigations in the Buddhist caves in Turfan]. In: Yakup, Abdurishid (ed.): Studies in Central Asian Philology. Papers of the International Symposium on Central Asian Philology, November 2012, Beijing. Beijing, Minzu University Press, pp. 138-160.

Li Yuan 李媛 (2010): Tulufan Tuyugou shiku yijian xin chutu wenshu de baohu yu xiufu 吐鲁 番吐峪沟石窟一件新出土文书的保护与修复 [Protection and restoration of a newly unearthed text in the Tuyoq Grottoes of Turfan]. Wenwu jianding yu jianshang 文物鉴定与鉴 赏 [Identification and appreciation to cultural relics] No. 11, pp. 108-110.

Li Yuqun 李裕群 - Li Xiao 李肖-Chen Ling 陈凌 (2011): Tuyugou shiku de xin faxian: yingxiang tulufan lishi de fojiao yizhi 吐峪沟石窟的新发现：影响吐鲁番历史的佛教遗址 [The new discovery of Tuyoq Grottoes: The Buddhist temple relics with significant influence on the history of Turfan]. Zhongguo wenhua yichan 中国文化遗产 [China cultural heritage] No. 2, pp. 66-73.

Moriyasu, Takao (2001): Uighur Buddhist Stake Inscriptions in Turfan. In: Bazin, Louis-Zieme, Peter (eds): De Dunhuang à Istanbul: Hommage à James Russel Hamilton. Turnhout, Brepols (Silk Road Studies 5), pp. 149-224.

Muller, A. Charles (1999): The Sutra of Perfect Enlightenment. Korean Buddhism's Guide to Meditation (with Commentary by the Sŏn monk Kihwa). Translated and with an introduction by A. Charles Muller. Albany, State University of New York Press.

Nakamura, Hajime 中村元 (1981): Bukkyōgo Daijiten 佛教語大辞典 [Great dictionary of Buddhist terms]. Tōkyō, Tōkyō Shoseki.

Raschmann, Simone-Christiane (2016): Uygur Scribbles on a Wooden Object. In: Russell-Smith, Lilla-Konczak-Nagel, Ines (eds): The Ruins of Kocho: Traces of Wooden Architecture on the Ancient Silk Road. Berlin, Museum für Asiatische Kunst, Staatliche Museen zu Berlin, pp. 42-48. 
Röhrborn, Klaus (2015): Uigurisches Wörterbuch. Sprachmaterial der vorislamischen türkischen Texte aus Zentralasien. Neubearbeitung, II. Nomina - Pronomina - Partikeln. Band 1: aasvik. Stuttgart, Franz Steiner Verlag.

Shōgaito, Masahiro 庄垣内正弘 (2008): Uigurubun abidaruma ronsho no bunkengaku teki kenkyū ウイグル文アビダルマ論書の文獻學的研究 [English title: Uighur Abhidharma Texts: A philological study]. Kyoto, Shoukadoh.

Shōgaito, Masahiro (2014): The Uighur Abhidharmakośabhāṣya Preserved at the Museum of Ethnography in Stockholm. Wiesbaden, Harrassowitz Verlag (Turcologica 99).

Wang, Huimin 王惠民 (1997): Lun “Siyijing” jiqi zai Dunhuang de liuchuan 论《思益经》及其 在敦煌的流传 [On the Viśeșacinti-brahma-paripṛcchā-sūtra and its spread in Dunhuang]. Dunhuang Yanjiu 敦煌研究 [Dunhuang research] No. 1, pp. 33-41.

Wilkens, Jens (2016): Buddhistische Erzählungen aus dem alten Zentralasien. Edition der altuigurischen Daśakarmapathāvadāna-mālā. 1-3. Turnhout, Brepols (Berliner Turfantexte XXXVII, $1-3)$.

Yakup, Abdurishid (2010): Prajñāpāramitā Literature in Old Uyghur. Turnhout, Brepols (Berliner Turfantexte XXVIII).

Zhang Tieshan (2017): A New Fragment of the Altun Yaruk in Old Uigur from Tuyuk. AOH Vol. 70, No. 4, pp. 411-416.

Zieme, Peter (1996): Altun Yaruq Sudur. Vorworte und das erste Buch. Turnhout, Brepols (Berliner Turfantexte XVIII).

Zieme, Peter (1999): The "Sūtra of Complete Enlightenment" in Old Turkish Buddhism. In: Collection of Essays 1993. Buddhism across Boundaries - Chinese Buddhism and the Western Regions. Taipei, Foguangshan Foundation for Buddhist \& Culture Education, pp. 449-483.

Zieme, Peter (2014): Neues zur altuigurischen Sitātapatrādhāraṇī. URL: http://www.academia.edu/ 15111985/Altuigurische_Texte_der_Kirche_des_Ostens_aus_Zentralasien._Gorgias_Eastern_ Christian_Studies_41 (Accessed: November 2014).

Zieme, Peter-Kara, Georg (1978): Ein uigurisches Totenbuch. Nāropas Lehre in uigurischer Übersetzung von vier tibetischen Traktaten nach der Sammelhandschrift aus Dunhuang British Museum Or. 8212 (109). Budapest, Akadémiai Kiadó (BOH XXII). 


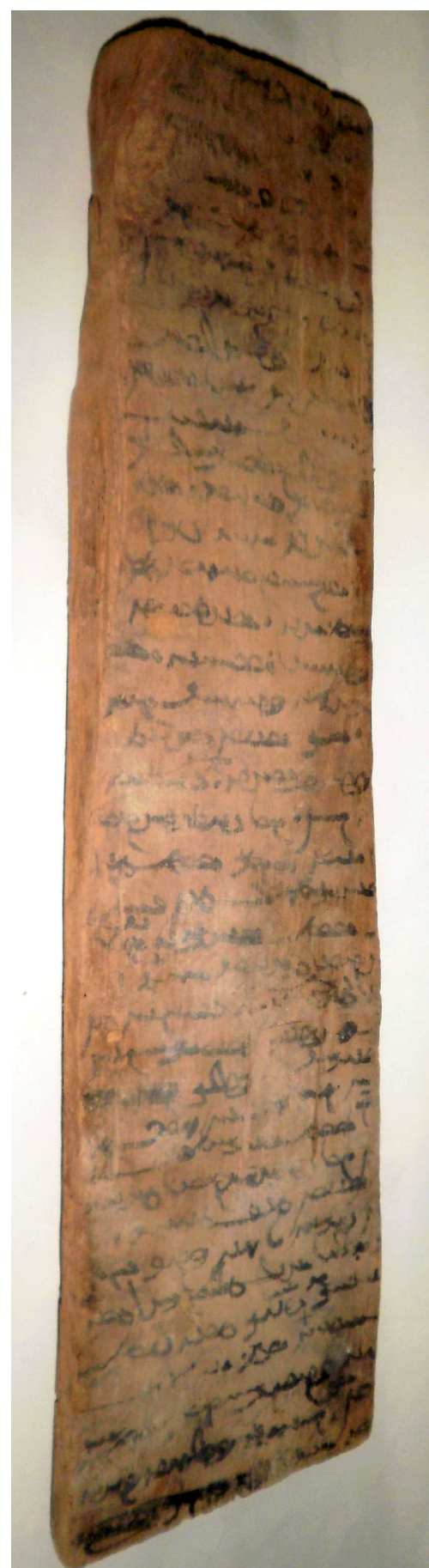

Side A

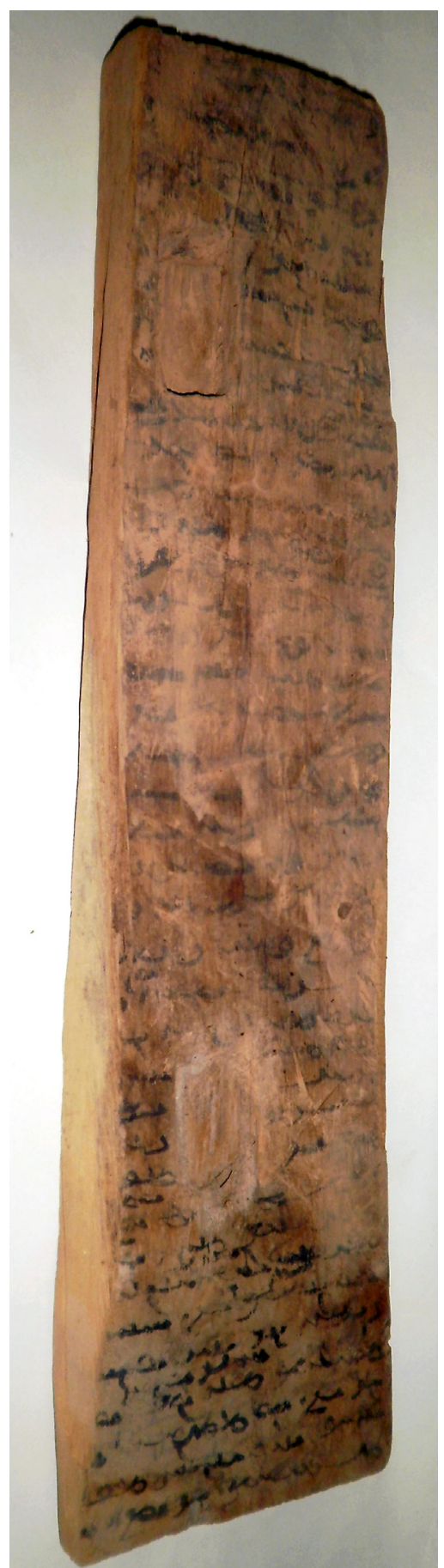

Side B 
